\title{
Strontium isotope ratios of some acid rocks from Mull and Arran, Scotland
}

SIR - During the course of a detailed investigation of the strontium isotope characteristics of acid and basic magmas from the Tertiary central complexes of Slieve Gullion and Carlingford, Northeast Ireland ( $\mathrm{O}^{\prime} \mathrm{Connor}$, in preparation), a few comparative analyses were made of acid rocks from Mull and Arran. The data are presented in Table 1 .

The Sr analyses were unspiked and performed on an AEI MS5 solid source mass spectrometer at the Department of Earth Sciences, Leeds. $\mathrm{Rb} / \mathrm{Sr}$ ratios, considered accurate to $\pm 1 \%$, were determined by the method of Pankhurst \& O'Nions (1973) on a Philips 1212 XRF using an Mo-target X-ray tube; the ${ }^{87} \mathrm{Rb} /{ }^{86} \mathrm{Sr}$ ratios of Table 1 were then calculated from the $\mathrm{Rb} / \mathrm{Sr}$ ratios. The mean of 10 analyses of the Eimer and Amend standard made during the course of this work was ${ }^{87} \mathrm{Sr} /{ }^{86} \mathrm{Sr} \pm 0.70811 \pm 4$ at the $95 \%$ confidence level. A more detailed account of the analytical techniques employed has been presented elsewhere (O'Connor, 1976).

The calculated initial ${ }^{87} \mathrm{Sr} /{ }^{86} \mathrm{Sr}$ ratios of the Beinn a'Ghràig granophyres of Mull are 0.7104 (Early Granophyre) and 0.7103 (Main Granophyre) assuming an age of $60 \mathrm{Ma}$ (results are quoted relative to an arbitrary value of ${ }^{87} \mathrm{Sr} /{ }^{86} \mathrm{Sr}=0.70800$ for the Eimer and Amend standard). These ratios compare very closely with the initial ratio of $0.7094 \pm 3$ reported by Beckinsale (1974) for the Glen Cannel Granophyre of Mull. Similar ratios of $0.7112 \pm 15$ were recorded by Moorbath \& Bell (1965) for the Redhills Epigranites of Skye.

The calculated initial ratio of the Northern Granite (Arran) is 0.7171 . This value represents the second highest ratio obtained to date on acid rocks from the Scottish and Irish Tertiary Province; the highest ratio obtained was that of $0.7201 \pm 20$ reported by Moorbath \& Bell (1965) for the Porphyritic Felsite of the Western Redhills Complex of Syke.

The data of Table 1 are consistent with the view that the initial ${ }^{87} \mathrm{Sr} /{ }^{80} \mathrm{Sr}$ ratios of acid rocks in the Tertiary Province of Northwest Scotland and Ireland are invariably $\geqslant 0.710$, and that they exceed significantly those of the basic rocks of the Province which tend to be confined to the range $0.704-0.707$.

The origin of these acid magmas is still in dispute. From geophysical evidence (Bott \& Tuson, 1973) it is clear that a copious supply of basic magma was available beneath most of the Tertiary centres. It has been suggested that the acid magmas have been produced by partial melting of crustal rocks in contact with these subjacent masses of basic magma (Brown, 1963; Moorbath \& Bell, 1965; Bell, 1966). In view of the large volumes of basic magma involved, some partial melting of crustal wall-ro:ks must have occurred. The volume of acid rocks at each centre, and the intimate spatial and temporal association of acid and basic magmas, together with the $\mathrm{Sr}$ and $\mathrm{Pb}$ isotope characteristics of the acid melts, are consistent with a partial melting hypothesis (Bell, 1966; Moorbath \& Welke, 1968).

The view that the acid rocks have been derived largely by differentiation of the basic magmas has recently received support (Beckinsale, 1974; Beckinsale, Thompson \& Durham, 1974). The striking lack of intermediate differentiation products (as distinct from products derived by hybridization) precludes any orthodox Bowen-type fractionation scheme and has not been adequately explained by proponents of this view. Moreover, the $\mathrm{Sr}$ and $\mathrm{Pb}$ isotopic data available indicate that even if some of the acid magmas were formed by differentiation they have been contaminated with crustally derived $\mathrm{Sr}$ and $\mathrm{Pb}$, either by mixing with partially-melted crustal rocks or by equilibration with crustal Sr and $\mathrm{Pb}$ (Moorbath \& Welke, 1968; Taylor \& Forester, 1971). Such

Geol. Mag. 113 (4), 1976, pp. 389-391. Printed in Great Britain. 
equilibration may have been aided significantly by the existence of hydrothermal convection systems around each intrusive centre (Taylor \& Forester, 1971).

In conclusion, the relative importance of the roles played by partial melting or differentiation processes in the production of the acid magmas of the Scottish Tertiary Province need to be critically assessed. It is clear that some of the acid magmas must have

Table 1. Initial strontium isotope ratios of acid rocks from Mull and Arran, Scotland

\begin{tabular}{|c|c|c|c|}
\hline & \multicolumn{3}{|c|}{ Sample (whole rocks) } \\
\hline & \multirow{2}{*}{$\begin{array}{c}\text { Isle of Arran, } \\
\text { Northern } \\
\text { Granite }\end{array}$} & \multicolumn{2}{|c|}{$\begin{array}{l}\text { Beinn a' Ghràig } \\
\text { Isle of Mull }\end{array}$} \\
\hline & & $\begin{array}{c}\text { Early } \\
\text { Granophyre }\end{array}$ & $\begin{array}{c}\text { Main } \\
\text { Granophyre }\end{array}$ \\
\hline $\begin{array}{l}\mathrm{Rb}^{*}(\mathrm{ppm}) \\
\mathrm{Sr} \text { (ppm) } \\
\mathrm{Rb} / \mathrm{Sr} \\
{ }^{87} \mathrm{Rb} /{ }^{88} \mathrm{Sr} \dagger \\
{ }^{87} \mathrm{Sr} /{ }^{88} \mathrm{Sr} \ddagger \\
\left({ }^{87} \mathrm{Sr} /{ }^{88} \mathrm{Sr}\right)_{0} \S\end{array}$ & $\begin{array}{c}165.3 \\
63.6 \\
2.60 \\
7.53 \\
0.72336 \pm 21 \\
0.7171\end{array}$ & $\begin{array}{c}163.0 \\
80.7 \\
2.02 \\
5.85 \\
0.71527 \pm 18 \\
0.7104\end{array}$ & $\begin{array}{c}184.6 \\
52.5 \\
3.52 \\
10.19 \\
0.71875 \pm 21 \\
0.7103\end{array}$ \\
\hline \multicolumn{4}{|c|}{$\begin{array}{l}\text { Analyst: P. J. O'Connor. } \\
\text { * Rb and } \mathrm{Sr} \text { determined by X-ray fluorescence. } \\
\text { † Calculated from XRF } \mathrm{Rb} / \mathrm{Sr} \text { ratios. } \\
\ddagger \text { Normalized by adjusting } \mathrm{Sr}^{88} / \mathrm{Sr}^{86}=8.375 \text { and the } \mathrm{Sr}^{87} / \mathrm{Sr}^{86} \text { ratio by half this amount; } \\
\text { esults are quoted relative to } \mathrm{Sr}^{87} / \mathrm{Sr}^{86}=0.70800 \text { for the Eimer and Amend standard; } \\
\text { rrors are one sigma. } \\
\S \text { Initial ratios calculated assuming an age of } 60 \mathrm{Ma} \text { and }{ }^{\lambda} \mathrm{Rb}=1.386 \times 10^{-11} \mathrm{yr}^{-1} \text {. }\end{array}$} \\
\hline
\end{tabular}

been derived by partial melting of crustal wall-rocks; no a priori reason exists for their production by differentiation and the arguments in favour of this mechanism seem far less conclusive. Even if such acid fractionation products exist, they have been contaminated with crustal $\mathrm{Sr}$ and $\mathrm{Pb}$ and can no longer be distinguished from melts derived from crustal sources. These 'limitations' of differentiation hypotheses would seem to need re-emphasis.

This letter is published with the permission of the Director of the Geological Survey of Ireland.

\section{References}

Beckinsale, R. D. 1974. Rb-Sr and K-Ar age determinations, and oxygen isotope data for the Glen Cannel Granophyre, Isle of Mull, Argyllshire, Scotland. Earth Planet. Sci. Lett. 22, 267-74.

Beckinsale, R. D., Thompson, R. B. \& Durham, J. J. 1974. Petrogenetic significance of initial $\mathrm{Sr}^{87} / \mathrm{Sr}^{86}$ ratios in the North Atlantic Tertiary Igneous Province in the light of $\mathrm{Rb}-\mathrm{Sr}, \mathrm{K}-\mathrm{Ar}$ and ${ }^{18} \mathrm{O}$ - abundance studies of the Sarqâta qáqâ Intrusive Complex, Ubekendt Ejland, West Greenland. J. Petrology 15, 525-38.

Bell, J. D. 1966. Granites and associated rocks of the eastern part of the Western Red Hills Complex, Isle of Skye. Trans. R. Soc. Edinb. 66, 307-43.

Bott, M. H. P. \& Tuson, J. 1973. Deep structure beneath the Tertiary volcanic regions of Skye, Mull and Ardnamurchan, Northwest Scotland. Nature, Phys. Sci. 242, 114-116.

Brown, G. M. 1963. Melting relations of tertiary granitic rocks in Skye and Rhum. Mineralog. Mag. 33, 533-62. 
Moorbath, S. \& Bell, J. D. 1965. Strontium isotope abundance studies and rubidiumstrontium age determinations on Tertiary igneous rocks from the Isle of Skye, Northwest Scotland. J. Petrology 6, 37-66.

Moorbath, S. \& Welke, H. 1968. Lead isotope studies on igneous rocks from the Isle of Skye, Northwest Scotland. Earth Planet. Sci. Lett 5, 217-230.

O'Connor, P. J. 1976. Rb-Sr whole-rock isochron for the Newry Granodiorite, N.E. Ireland. Scient. Proc. R. Dubl. Soc. 5, 407-13.

Pankhurst, R. J. \& O'Nions, R. K. 1973. Determination of $\mathrm{Rb} / \mathrm{Sr}$ and $\mathrm{Sr}^{87} / \mathrm{Sr}^{80}$ ratios of some standard rocks and evaluation of X-ray fluorescence spectrometry in Rb-Sr geochemistry. Chem. Geol. 12, 127-36.

Taylor, H. P. Jr. \& Forester, R. W. 1971. Low-O ${ }^{18}$ igneous rocks from the intrusive complexes of Skye, Mull and Ardnamurchan, Western Scotland. J. Petrology 12, 465-97.

Geological Survey of Ireland

P. J. O'CONNOR

14 Hume Street

Dublin 2

Ireland

29th January 1976 